\title{
Effect of Salinity on Growth, Xylem Structure and Anatomical Characteristics of Soybean
}

\author{
Aria DOLATABADIAN ${ }^{1}$, Seyed Ali Mohammad MODARRES SANAVY'1 , Faezeh GHANATI ${ }^{2}$ \\ ${ }^{1}$ Tarbiat Modares University, Faculty of Agriculture, Agronomy Department, Tehran, Iran; modaresa@modares.ac.ir \\ ${ }^{2}$ Tarbiat Modares University, Faculty of Basic Science, Plant Biology Department, Tehran, Iran
}

\begin{abstract}
This research was conducted in order to evaluation the salinity stress effect on growth parameters and stem anatomical changes of soybean grown under controlled conditions. Soybean seeds were surface sterilized and then sown into plastic pots filled up with perlite and vermiculite. Seeds were irrigated with Broughton and Dilworth solution daily. At full folded cotyledons stage ( 5 day after sowing), salinity stress was induced by adding $\mathrm{NaCl}$ into nutrition solution with final concentration of $0,25,50$ and $100 \mathrm{mM}$. Thirty days after sowing plants were harvested and growth parameters and anatomical changes were evaluated. The results showed that, salinity stress was significantly decreased shoot and root weight either fresh weight or dry weight, in addition, total plant weight, plant height and leaf number were decreased due to salinity stress. Interestingly, leaf area was not affected by salinity stress. Stem microscopic study demonstrated that, salinity stress significantly increased cutin mass and trichome density on epidermal cells. On the other hand, cortex thickness was decreased because of salinity stress while xylem thickness had upward increase when soybean plants were grown under salinity stress especially high level of salinity. Additionally, there were changed in xylem formation and arrangement in stressed plants.
\end{abstract}

Keywords: anatomical characteristic, growth, salinity stress, soybean

\section{Introduction}

One of the most widespread agricultural problems in arid and semiarid regions is soil salinity, which makes fields unproductive and decreases crop yield. All natural waters contain soluble salts. The concentration of the salts determines whether the water is of high quality or of low quality. Salinity becomes a concern when an excessive amount or concentration of soluble salts occurs in the soil or water. In general, $\mathrm{NaCl}$ is the most common salt. It has been reported that salinity limits plant growth and productivity (Ashraf and Foolad, 2006; Ghazi and Al-Karaki, 2006). Salinity stress decreases photosynthetic capacity, due to the osmotic stress and partial closure of stomata (Drew et al., 1990). Salt stress also affects phytohormones which are naturally occurring organic substances, influencing physiological processes at low concentrations either in distant tissues to which they are transported or in the tissue where synthesis occurred (Davies, 1995). It is evident that there are big changes in morphology and anatomy of plants growing in saline soils. The effect of salinity on root (An et al., 2003) and leaf anatomy (Hu and Schmidhalter, 2001; Kiliç et al., 2007) of plants had already been reported in previous works. Many researchers reported that with an increase in salinity there was a decrease in the development of the xylem. Pimmongkol et al. (2002) stated that the width of vascular bundles and diameters of rice stems decreased in $\mathrm{NaCl}$ medium. Junghans et al. (2006) showed that high salt concentrations reduced the cambial activity in Populus euphratica. Salinity causes reduced total leaf area (Awang et al., 1993), and increased leaf thickness (Raafat et al., 1991). Salinity also reduces development of vascular tissue (Belda and Ho, 1993), increases trichome density and decreases or has no effect on stomatal density (Ludders and Kaminski, 1991).

Soybean is one of the most important fabaceae plants. It is also considered as a good source of vegetable protein and oil since it has the highest level of protein in comparison with the other leguminous plants (Moussa, 2004). In soybean, salinity stress inhibits seed germination and seedling growth, reduces nodulation, and decreases biomass accumulation and yield (Essa, 2002). Unfortunately, there are fewer studies on the effect of salinity on stems anatomy of soybean. Thus, we investigated the effect of $\mathrm{NaCl}$ induced stress on growth attributes and stem anatomical characteristics of soybean. The objectives of this study were to determine whether these traits were affected differently when the soybean plants were grown under salinity stress.

\section{Materials and methods}

Seeds of the soybean [Glycine $\max$ (L.) Merr.] c.v. 'L17' were surface sterilized in hydrogen peroxide/ethanol solution $\left(10 \mathrm{ml}\right.$ of $30 \% \mathrm{H}_{2} \mathrm{O}_{2}$ and $75 \mathrm{ml}$ of $96 \%$ ethanol filled up to $100 \mathrm{ml}$ with sterile distilled water) and rinsed several times with sterile water. The surface sterilised soybean seeds were sown into plastic pots filled up with 1:1 autoclaved perlite and vermiculite at depth of 1-2 cm. Four seeds were 
42

sown in each pot. The pots were placed into a growth cabinet $\left(\mathrm{L} / \mathrm{D}=16 / 8 \mathrm{~h}, \mathrm{~T}=28 / 25^{\circ} \mathrm{C}\right)$, and watered with full strength of Broughton and Dilworth solution containing $8 \mathrm{mM} \mathrm{KNO}_{3}$ (Broughton and Dilworth, 1971).

All seedlings were inoculated with Bradyrhizobium japonicum. The inoculant was produced by culturing $B$. japonicum in yeast extract-mannitol broth (YMB) in 250 $\mathrm{ml}$ flasks shaken at $150 \mathrm{rpm}$ at $28^{\circ} \mathrm{C}$. The five days old plants were inoculated with a liquid $\mathrm{YMB}$ and watered with $\mathrm{B} \& \mathrm{D}$ solution containing $2 \mathrm{mM} \mathrm{KNO}$ supplemented with 25, 50 and $100 \mathrm{mM} \mathrm{NaCl}$. Control plants were maintained in a $\mathrm{NaCl}$-free solution. Two times a week, the plants were also watered with distilled water to prevent of salt accumulation. An excess of drain water was removed from the saucers. After 30 days after sowing the soybean plants were removed from the pots. The roots were gently washed with water to remove all perlites and vermiculites and then shoot and root were detached and weighted. Number of leaves was counted and also leaf area was measured by leaf area meter (Delta-T Devices LTD, England), afterwards the samples were dried at $70^{\circ} \mathrm{C}$ for $24 \mathrm{~h}$ to calculate dry weight. Stem sample of each treatment was taken and fixed into $70 \%$ ethanol for anatomical assay. Stem sections were cut with a razor blade and placed in distilled water and observed under fluorescence microscopy. Olympus microscope equipped with a digital camera was used; the study was conducted in Faculty of Agriculture, Tarbiat Modares University, Tehran, Iran.

The experiment was structured following a Completely Randomized Design (CRD) with three replications. For all variables, analysis of variance (ANOVA) was performed. The significance of differences among treatment means were compared by Duncan's Multiple Range Test (DMRT).

\section{Results and discussion}

The analysis of variance showed a significant effect $(p<0.01)$ on all traits due to salinity stress. The results are shown in Tab. 1. In addition, comparison of means by Duncan's Multiple Range Test demonstrated that, salinity stress decreased root weight either fresh weight or dry weight (Tab. 2). Decrease in root weight was parallel with enhancement of $\mathrm{NaCl}$ concentration in nutrition solution. The highest root weights (fresh or dry weight) were obtained in control treatment while the lowest one was observed in $100 \mathrm{mM} \mathrm{NaCl}$ treatment (Tab. 2). Similar results were achieved when shoot fresh weight and then shoot dry weight were measured. The highest and the lowest shoot weights were related to control treatment and $100 \mathrm{mM} \mathrm{NaCl}$ treatment, respectively (Tab. 2). Salinity stress was diminished plant growth and significantly decreased total dry weight. There was downward decrease in shoot weight because of deterrent effect of salinity on plant height (Tab. 2). Salt stress adversely affects the growth and development of crops, and the results of our study confirm that all growth variables of soybean drastically decreased with $\mathrm{NaCl}$ treatment. It has been reported that the plants had the reduction in their fresh weights because of the proportional increase in $\mathrm{Na}^{+}$concentration, which could imply that an ionic effect was being manifested. It is also assumed that in addition to toxic effects of $\mathrm{NaCl}$, higher concentration of salt reduces the water potential in the medium which hinders water absorption and thus reduces plant growth. Sagi et al. (1997) also found the adverse effects of salinity stress on shoot and root growth. It has been reported that, decline in plant biomass may be due to excessive accumulation of $\mathrm{NaCl}$ in chloroplasts of soybean, which affects growth rate, and is often associated with a decrease in the electron transport activities of photosynthesis (Kirst, 1989) and inhibition of PSII activity (Kao et al., 2003). In general, salinity reduces leaf number, leaf area, shoot and root dry weight, leading to low yields (Essa, 2002; Hamdy et al., 1993; Li et al., 2006; Sharifi et al., 2007).

There was no significant difference between control and $25 \mathrm{mM} \mathrm{NaCl}$ treatments on plant height, while increase of $\mathrm{NaCl}$ concentration from $25 \mathrm{mM}$ to $50 \mathrm{mM}$ and finally to $100 \mathrm{mM}$ dramatically decreased plant height (Tab. 2). Reduction in growth attributes especially plant height may be due to changes in plant-water relationships under salt stress, which suppress meristem activity as well as cell elongation (Dorgham, 1991). Data reported by Essa (2002) showed that reduction of $4 \%$ in plant height and in dry weight, at 45 days after planting of soybean under increase of soil salinity.

Leaf number was not affected by 25 and $50 \mathrm{mM} \mathrm{NaCl}$ concentrations so that there was not significant difference between those treatments in compare with control but increase of salinity to $100 \mathrm{mM}$ significantly decreased leaf number, which confirms the results of Ünlükara et al. (2008). Inhibition of the formation of leaf primordia under salinity stress could be the probable reason for low leaf number. Iyenger et al. (1977) reported that saline irrigation water reduced the number of leaves.

Also there was no significant difference among salinity treatments on leaf area (Tab. 2). Our results are inconsistence with Gosset and Lucas (1994) who reported that $\mathrm{NaCl}$ highly reduced total leaf area; it seems that plant height was more sensitive to salinity than leaf number or leaf area expansion.

Pearson correlations between growth parameters are given in Tab. 3. Briefly, there were positive and significant correlations between all traits except leaf number and root dry weight.

Microscopic results showed that salt induced increment in cutin synthesis on epidermal cells. Enhancement of salinity level increased cutin layer thickness in compare with control treatment. Cutin layer is distinguishable by a bright and orange layer on the epidermal cells under florescence microscope (Fig. 1 and Fig. 2). The plant cuticle is a lipidic layer of cutin that covers essentially all aerial organs 
Tab. 1. Analysis of variance on soybean growth parameters affected by salt stress

\begin{tabular}{cccccccccc}
\hline $\begin{array}{c}\text { Sources of } \\
\text { variation }\end{array}$ & df & $\begin{array}{c}\text { Root fresh } \\
\text { weight }\end{array}$ & $\begin{array}{c}\text { Root dry } \\
\text { weight }\end{array}$ & $\begin{array}{c}\text { Shoot fresh } \\
\text { weight }\end{array}$ & $\begin{array}{c}\text { Shoot dry } \\
\text { weight }\end{array}$ & $\begin{array}{c}\text { Total dry } \\
\text { weight }\end{array}$ & $\begin{array}{c}\text { Plant } \\
\text { height }\end{array}$ & $\begin{array}{c}\text { Leaf } \\
\text { number }\end{array}$ & $\begin{array}{c}\text { Leaf } \\
\text { area }\end{array}$ \\
\hline Treatment & 3 & $0.817^{* *}$ & $0.323^{* *}$ & $1.780^{* *}$ & $1.060^{* *}$ & $2.549^{* *}$ & $134.000^{* *}$ & $0.666^{* *}$ & $409.888 \mathrm{~ns}$ \\
Error & 8 & 0.004 & 0.018 & 0.003 & 0.016 & 0.033 & 2.333 & 0.083 & 16.000 \\
CV $(\%)$ & & 2.76 & 34.57 & 2.21 & 17.64 & 16.35 & 4.09 & 7.87 & 2.77 \\
\hline
\end{tabular}

${ }^{* *}$ significant at the 0.01 probability levels

Tab. 2. Means comparison of soybean growth parameters affected by salt stress

\begin{tabular}{ccccccccc}
\hline Treatments & $\begin{array}{c}\text { Root fresh } \\
\text { weight }(\mathrm{g})\end{array}$ & $\begin{array}{c}\text { Root dry } \\
\text { weight }(\mathrm{g})\end{array}$ & $\begin{array}{c}\text { Shoot fresh } \\
\text { weight }(\mathrm{g})\end{array}$ & $\begin{array}{c}\text { Shoot dry } \\
\text { weight }(\mathrm{g})\end{array}$ & $\begin{array}{c}\text { Total dry } \\
\text { weight }(\mathrm{g})\end{array}$ & $\begin{array}{c}\text { Plant height } \\
(\mathrm{cm})\end{array}$ & $\begin{array}{c}\text { Leaf } \\
\text { number }\end{array}$ & $\begin{array}{c}\text { Leaf area } \\
(\mathrm{cm})\end{array}$ \\
\hline $0 \mathrm{mM}(\mathrm{Control})$ & $2.94 \mathrm{a}$ & $0.82 \mathrm{a}$ & $3.49 \mathrm{a}$ & $1.54 \mathrm{a}$ & $2.36 \mathrm{a}$ & $42.00 \mathrm{a}$ & $4.00 \mathrm{a}$ & $152.33 \mathrm{a}$ \\
$25 \mathrm{mM} \mathrm{NaCl}$ & $2.57 \mathrm{~b}$ & $0.45 \mathrm{~b}$ & $2.74 \mathrm{~b}$ & $0.76 \mathrm{~b}$ & $1.22 \mathrm{~b}$ & $42.33 \mathrm{a}$ & $4.00 \mathrm{a}$ & $150.66 \mathrm{a}$ \\
$50 \mathrm{mM} \mathrm{NaCl}$ & $2.11 \mathrm{c}$ & $0.19 \mathrm{c}$ & $2.15 \mathrm{c}$ & $0.44 \mathrm{c}$ & $0.63 \mathrm{c}$ & $37.00 \mathrm{~b}$ & $3.66 \mathrm{a}$ & $146.66 \mathrm{a}$ \\
$100 \mathrm{mM} \mathrm{NaCl}$ & $1.74 \mathrm{~d}$ & $0.08 \mathrm{c}$ & $1.71 \mathrm{~d}$ & $0.17 \mathrm{~d}$ & $0.25 \mathrm{~d}$ & $28.00 \mathrm{c}$ & $3.00 \mathrm{~b}$ & $127.00 \mathrm{a}$ \\
\hline
\end{tabular}

Within each column followed by the same letter are not significantly differences $(\mathrm{p}<0.05)$

Tab. 3. Pearson correlations between growth parameters affected by salt stress

\begin{tabular}{|c|c|c|c|c|c|c|c|c|}
\hline & $\begin{array}{c}\text { Root fresh } \\
\text { weight }\end{array}$ & $\begin{array}{c}\text { Root dry } \\
\text { weight }\end{array}$ & $\begin{array}{c}\text { Shoot fresh } \\
\text { weight }\end{array}$ & $\begin{array}{c}\text { Shoot dry } \\
\text { weight }\end{array}$ & $\begin{array}{c}\text { Total dry } \\
\text { weight }\end{array}$ & $\begin{array}{l}\text { Plant } \\
\text { height }\end{array}$ & $\begin{array}{c}\text { Leaf } \\
\text { number }\end{array}$ & $\begin{array}{l}\text { Leaf } \\
\text { area }\end{array}$ \\
\hline Root fresh weight & 1 & & & & & & & \\
\hline Root dry weight & $0.92^{* *}$ & 1 & & & & & & \\
\hline Shoot fresh weight & $0.97^{* *}$ & $0.92^{* *}$ & 1 & & & & & \\
\hline Shoot dry weight & $0.94^{* *}$ & $0.90^{* *}$ & $0.96^{* *}$ & 1 & & & & \\
\hline Total dry weight & $0.95^{* *}$ & $0.96^{* *}$ & $0.97^{* *}$ & $0.98^{* *}$ & 1 & & & \\
\hline Plant height & $0.88^{* *}$ & $0.72^{* *}$ & $0.83^{* *}$ & $0.75^{* *}$ & $0.75^{* *}$ & 1 & & \\
\hline Leaf number & $0.74^{* *}$ & $0.52 \mathrm{~ns}$ & $0.75^{* *}$ & $0.66^{*}$ & $0.62^{*}$ & $0.87^{* *}$ & 1 & \\
\hline Leaf area & $0.81^{* *}$ & $0.68^{*}$ & $0.79^{* *}$ & $0.70^{*}$ & $0.71^{* *}$ & $0.96^{* *}$ & $0.87^{* *}$ & 1 \\
\hline
\end{tabular}

${ }^{*},{ }^{* *}$ significant at the 0.05 and 0.01 probability levels, respectively
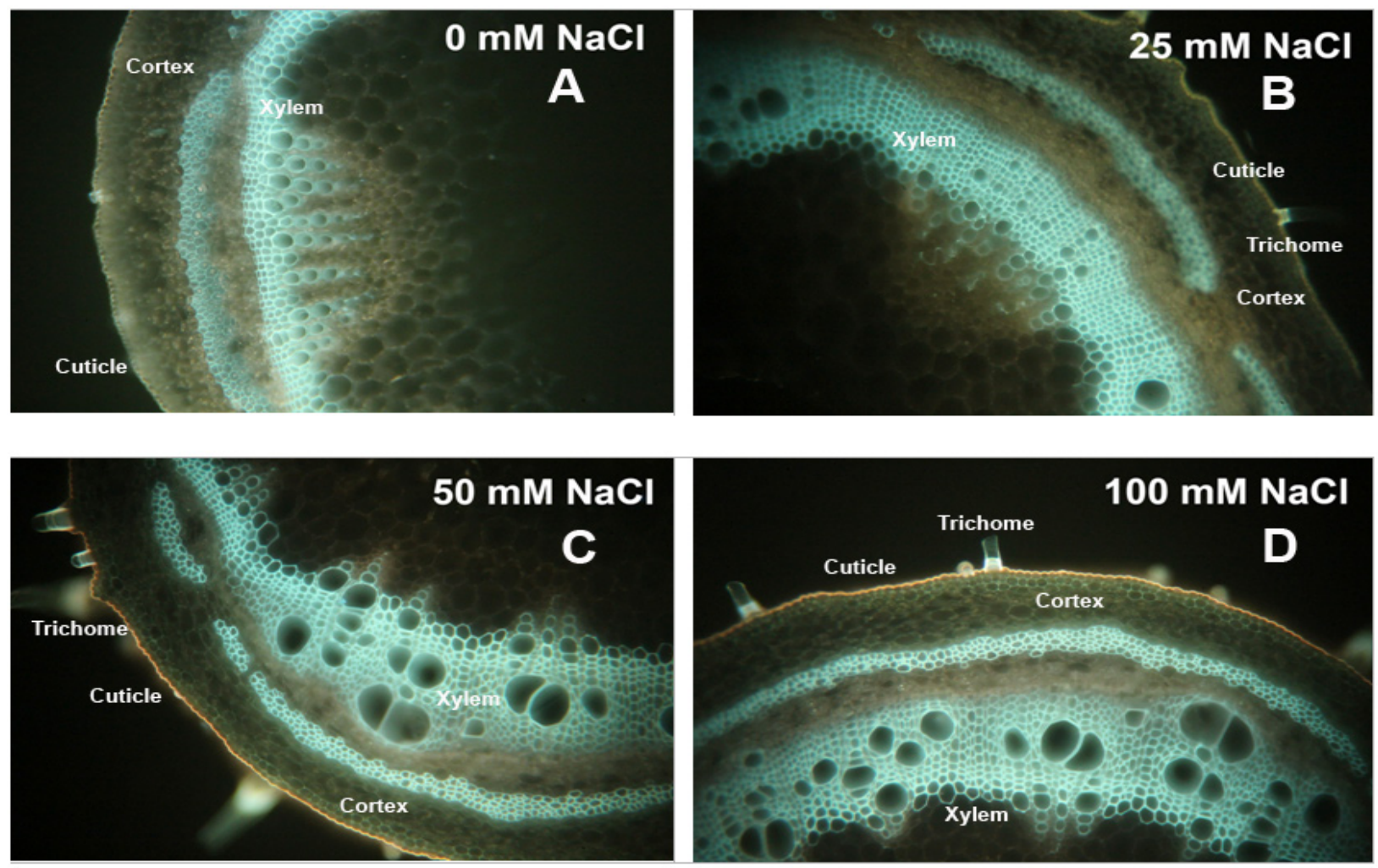

Fig. 1. Microscopic photos of stem sections treated by different concentration of $\mathrm{NaCl}$ 
44

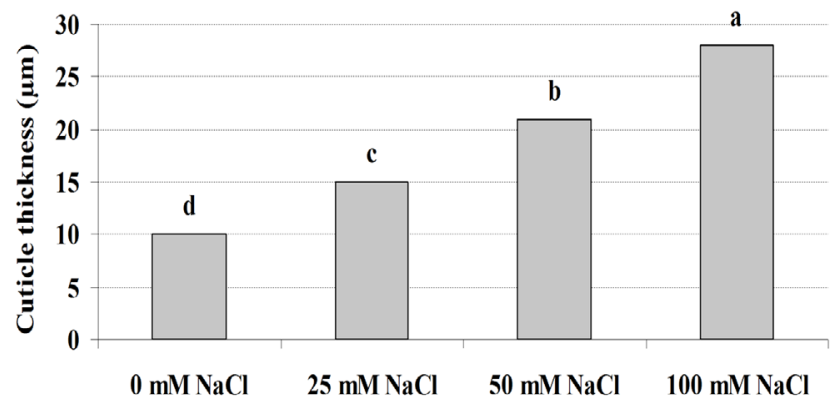

Fig. 2. Changes in stem cuticle thickness affected by different salinity stress. Within each column followed by the same letter are not significantly differences $(\mathrm{p}<0.05)$

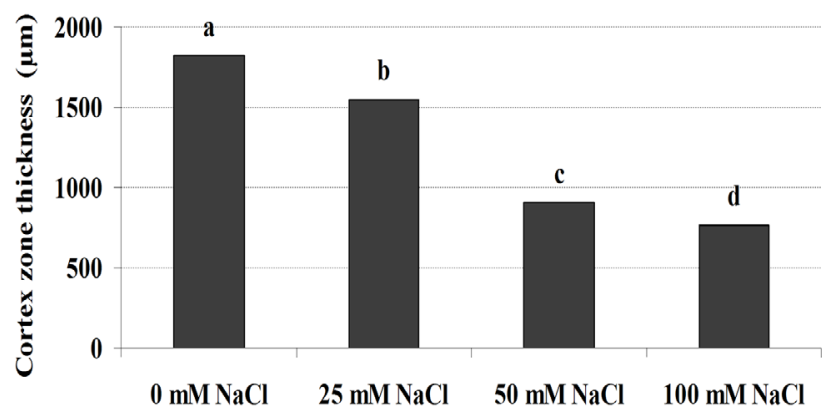

Fig. 3. Changes in stem cortex zone thickness affected by different salinity stress. Within each column followed by the same letter are not significantly differences $(\mathrm{p}<0.05)$

and functions to restrict transpiration. By this mechanism, the cuticle is thought to play a critical role in plant tolerance through its ability to postpone the onset of cellular dehydration during stress (Kosma and Jenks, 2007; Samuels et al., 2008). Our results, which show a significant increase in cutin and an increase in the thickness of cuticle after salt stress, lead us to speculate that salinity involves synthesis of cutin.

Furthermore, we observed that, in salt stressed plants, number of trichomes was increased from epidermal stem cells. In the other word, increase of salinity level led to more trichomes on epidermal layer in compare with control plants (Data are not shown) (Fig. 1). There are several reports on increased trichome density under environmental stresses such as drought and salinity (Abernethy et al., 1998; Aguirre-Medina et al., 2002). Increase of trichome density may be a mechanism to increase of tolerance to salt stress. It was recently suggested that leaf glandular trichomes could contribute to the high salt tolerance by the excretion of ions (Gucci et al., 1997).

Salinity induced structural changes in xylems in stems. In salt stressed plants, stems vascular cell thickness was much larger than control treatment; the salinity effect was concentration dependent. Generally, plants grown in saline solution showed higher thickness in cuticle, vascular tissues and vessel than unstressed plant while cortex zone thickness was decreased (Fig. 1 and Fig. 3). Cell walls are known to become lignified when cell expansion decreases,

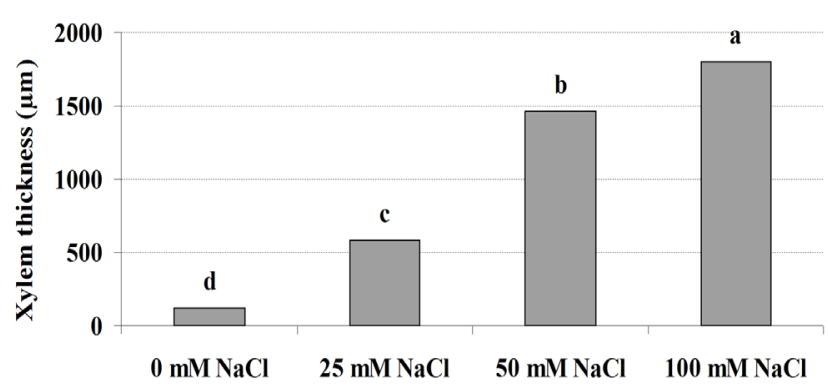

Fig. 4. Changes in stem xylem thickness affected by different salinity stress. Within each column followed by the same letter are not significantly differences $(\mathrm{p}<0.05)$

when the cell is under stress and when it differentiates to particular specialized tissues, notably the xylem (Christensen et al., 1998). Salinity stress has been associated with a greater deposition of lignin in vascular tissues and/ or xylem development. In bean-root vascular tissue, $\mathrm{NaCl}$ caused earlier and stronger lignifications, which has been suggested to be a factor that inhibits root growth and, consequently, represents an adaptation mechanism in resisting salinity-imposed stress (Cachorro et al., 1993). In this study saline stress induced acceleration of the development of xylem and phenolic compounds in soybean stems (Fig. 1 and Fig. 4).

In conclusion, this study shows that salt stress decreases soybean growth and induces changes in anatomical characteristics such as increment of cutin synthesis on epidermal stem cells and also changes in xylem structure and lignification of them in soybean stems.

\section{References}

Abernethy GA, Fountain DW, McManus MT (1998). Observations on the leaf anatomy of Festuca novae-zelandiae and biochemical responses to a water deficit. $\mathrm{N} \mathrm{Z} \mathrm{J} \mathrm{Bot}$ 36:113-123.

Aguirre-Medina JF, Acosta Gallegos JA, del. Ruiz Posadas L, Shibata JK, Trejo Lopez C (2002). Morphological differences on the leaf epidermis of common bean and their relationship to drought tolerance. Agricultura technical en Mexico 28:53-64.

An P, Inanaga S, Li X, Schimizu H, Tanimoto E (2003). Root characteristics in salt tolerance. Root Res 12:125-132.

Ashraf M, Foolad MR (2007). Roles of glycine betaine and proline in improving plant abiotic stress resistance. Environ Exp Bot 59:206-216.

Awang YB, Atherton JG, Taylor AJ (1993). Salinity effects on strawberry plants in rockwool. 1. Growth and leaf water relations. J Hortic Sci 68:783-790.

Belda RM, Ho LC (1993). Salinity effects on the network of vascular bundles during tomato fruit development. J Hortic Sci 68:557-564.

Broughton WJ, Dilworth MJ (1971). Control ofleghaemoglobin 
synthesis in snake beans. Biochem J 125:1075-1080.

Cachorro P, Ortiz A, Barcelo AR, Cerda A (1993). Lignin deposition in vascular tissues of Phaseolus vulgaris roots in response to salt stress. Phyton-Ann Rei Bot 33:33-40.

Christensen JH, Bauw G, Welinder KG, Van Montagu M, Boerjan W (1998). Purification and characterization of peroxidases correlated with lignification in poplar xylem. Plant Physiol 118:125-135.

Davies PJ (1995). The plant hormones: their nature, occurrence and functions, p. 1-12. In: Davies PT (Ed.). Plant Hormones. Kluwer Academic Publishers, Netherlands.

Dorgham EA (1991). Effect of Water Stress, Irradiation and Nitrogen Fertilization on Grain Filling, Yield and Quality of Certain Wheat Cultivars. Ph.D. Thesis, Ain Shams University of Cairo, Egypt.

Drew MC, Hole PS, Picchioni GA (1990). Inhibition by $\mathrm{NaCl}$ of net CO fixation and yield of cucumber. J Amer Soc Hort Sci 115:472-477.

Essa TA (2002). Effect of salinity stress on growth and nutrient composition of three soybeans (Glycine max (L.) Merrill) cultivars. J Agro and Crop Sci 188:86-93.

Essa TA (2002). Effect of salinity stress on growth and nutrient composition of three soybean (Glycine max L. Merrill) Cultivars. J Agron Crop Sci 188:86-93.

Ghazi N, Al-Karaki GN (2006). Nursery inoculation of tomato with arbuscular mycorrhizal fungi and subsequent performance under irrigation with saline water. Sci Hort 109:1-7.

Gossett DR, Lucas MC (1994). Antioxidant response to $\mathrm{NaCl}$ stress in salt tolerant and salt sensitive cultivars of cotton. Crop Sci 34:706-714.

Gucci R, Aronne G, Lombardini L, Tattini M (1997). Salinity tolerance in Phillyrea species. New Phytol 135:227-234.

Hamdy A, Abdul-Dayem S, Abu-Zeid M (1993). Saline water management for optimum crop production. Agric Water Management 24:189-203.

$\mathrm{Hu}$ Y, Schmidhalter U (2001). Reduced cellular crosssectional area in the leaf elongation zone of wheat causes a decrease in dry weight deposition under saline conditions. Aust J Plant Physiol 28:165-170.

Iyengar ERR, Patolia JS, Kurian T (1977). Varietal difference of barley to salinity. Z Pflanzen Physiol 84:355-362.

Junghans U, Polle A, Duchting P, Weiller E, Kuhlman B, Gruber F, Teichmann T (2006). Adaptation to high salinity in poplar involves changes in xylem anatomy and auxin physiology. Plant Cell Environ 29:1519-1531.

Kao WY, Tsai T, Shih CN (2003) Photosynthetic gas exchange and chlorophyll a fluorescence of three wild soybean species in response to $\mathrm{NaCl}$ treatments. Photosynthetica 41:415 419.
Kılıç S, Çavuşoğlu K, Kabar K (2007). Effects of ${ }^{45}$ 4epibrassinolide on salinity stress induced inhibition of seed germination, seedling growth and leaf anatomy of barley. SDU Fac Arts Sci J Sci. 2:41-52.

Kirst GO (1989). Salinity tolerance of eukaryotic marine algae. Plant Mol Biol 40:21-53.

Kosma DK, Jenks MA (2007). Eco-physiological and moleculargenetic determinants of plant cuticle function in drought and salt stress tolerance, p. 91-120. In: Jenks MA, Hasegawa PM and Jain SM (Eds.). Advances in Molecular Breeding toward Drought and Salt Tolerant Crops. Springer, Dordrecht, The Netherlands.

Li X, An P, Inanaga S, Eneji AE, Tanabe K (2006). Salinity and Defoliation Effects on Soybean Growth. J Plant Nutr 29:1499-1508.

Ludders PC, Kaminski V (1991). Einflub von $\mathrm{NaCl}$ auf die stomata- und blatthaardichte bei feigen in unterschiedlicher luftfeuchte. Mitteilungen Klosterneuburg 41:76-78.

Moussa HR (2004). Amelioration of Salinity-Induced Metabolic Changes in Soybean by Weed Exudates. Int J Agr Biol 6:499-503.

Pimmongkol A, Terapongtanakhon S, Udonsirichakhon K (2002). Anatomy of salt-and non-salt-tolerant rice treated with $\mathrm{NaCl}$. In: $28^{\text {th }}$ Congr. Science and Technology of Thailand, Bangkok, Thailand.

Raafat A, Habib SA, El-Shami IZ, El-Antably HM (1991). The effect of salinity on the anatomical features of tomato plants. Ann Agric Sci 36:307-321.

Sagi M, Savidov NA, Vov NPL, Lips SH (1997). Nitrate reductase and molybdenum cofactor in annual ryegrass as affected by salinity and nitrogen source. Physiol Plant 99:546-553.

Samuels AL, Kunst L, Jetter R (2008). Sealing plant surfaces: cuticular wax formation by epidermal cells. Annu Rev Plant Biol 59:683-707.

Sharifi M, Ghorbanli M, Ebrahimzadeh H (2007). Improved growth of salinity-stressed soybean after inoculation with salt pre-treated mycorrhizal fungi. J Plant Physiol 164:11441151.

Ünlükara A, Cemek B, Karaman S, Erşahin S (2008). Response of lettuce (Lactuca sativa var. crispa) to salinity of irrigation water. NewZealand J Crop Hort Sci 36:265-273. 